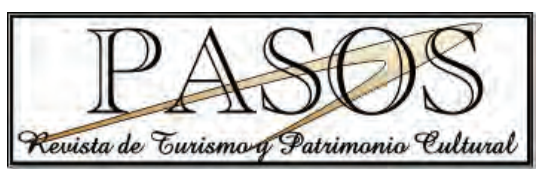

www.pasosonline.org

\title{
Destination image: Origins, Developments and Implications
}

\author{
Sérgio Dominique Ferreira Lopes ${ }^{i}$ \\ Polytechnic Institute of Cávado and Ave (Portugal) \\ Universidad de Santiago de Compostela (España)
}

\begin{abstract}
Over the last few decades, tourism has become one of the main sectors of the global economy, not only because of its contribution to the Gross Domestic Product (GDP) of different countries, but also because of the employment it generates. Since 2009, however, the results of tourism have been severely affected by the economic and financial crisis and it is now essential to analyze the key elements of tourist consumer behavior. In this context, the image that a destination transmits to the market becomes one of the elements which influence tourists the most when choosing a tourist destination. The authors therefore aim to identify the main elements that characterize the image of a tourist destination, as well as their implications for the management of tourist destinations.
\end{abstract}

Keywords: Tourism Management; Marketing; Brand Image; Destination Image

Título: Imagen de destino: Orígenes, desarrollos e implicaciones .

Resumen: O objeto de estudo do artigo é o conjunto arquitetônico e paisagístico de Igarassu, mais especificamente as inter-relações entre patrimônio cultural, turismo e gestão pública no sítio histórico. O trabalho de campo mostrou que o atual padrão de exploração turística é um instrumento de desvalorização e deterioração desse patrimônio, deixando reduzidos benefícios à cidade. Isso é resultado do controle externo do fluxo de turistas e visitantes, bem como da falta de controle e regulação públicos efetivos da prefeitura municipal. Considerando as características do mercado turístico, especificamente das agências e guias de turismo, e da gestão pública em Igarassu, avaliam-se como improváveis mudanças relevantes nas inter-relações supracitadas, pelo menos a curto e médio prazo.

Palabras clave: Gestión Turística; Marketing; Imagen de Marca; Imagen de Destinos Turísticos.

i PhD in Marketing by the University of Santiago de Compostela. Professor at the School of Management - Polytechnic Institute of Cávado and Ave, Portugal. Email: sdominique@ipca.pt 


\section{The Importance of Tourism}

Tourism has become one of the most important sectors of the global economy (Ferreira, Rial and Varela, 2009). According to the World Tourism Organization (UNWTO, 2009), in 2008, the number of international tourist arrivals came to 924 million, representing an increase of $2 \%$ (16 million) compared to 2007 . Revenues increased to 642 billion Euros in 2008, i.e., an increase of $1.7 \%$ compared to 2007 . However, the results of 2009 worsened due to the international crisis (Rial, Ferreira and Varela, 2009). Thus, every effort should be made to achieve sustainable growth for tourism. In this context, special attention has to be paid to the study and assessment of brand image or destination image (in the context of tourism) because it is one of the most important elements of a tourist destination.

\section{Brand Image}

Strategically speaking, marketing management requires a careful analysis of the brand image transmitted to the market, because it is precisely this image that will affect consumer choice. As such, brand management often relies on a medium-long term strategy, based on the objectives of the brand (Moutinho, 1987; García, 2002; Rial, \& García Varela, 2008). In the context of modern marketing, brand image becomes a major factor in the success of any organization (Aaker, 1991), and is the result of sensory experiences and internal imitation created by perceptual processes (Paivio, 1971).

According to the World Tourism Organization, the image of an object or situation is defined as:

- The artificial imitation of the apparent form of an object.

- Similarity or identity with the form (e.g.: art or design).

- Individual or collective ideas about the destination.

In this sense, Bauerle (1983) defines brand image as a mental representation, while Costa (1987) defines it as a mental representation in the collective memory of a stereotype or a set of attributes that can influence and change consumer behavior. Both authors (Bauerle, 1983; Costa, 1987) present the concept of brand image as a mental representation.

Keller (1993) defines brand image more succinctly as a set of perceptions about a brand, i.e., the associations that exist in the consumer's memory. Sanz de Tajada (1996) describes image as a set of notes associated spontaneously with a given stimulus which has previously triggered a set of associations that make up a body of knowledge (beliefs) in the consumer.
Based on these multiple definitions of brand image, Capriotti (1992) identifies three (3) theoretical perspectives:

- The image as fiction: the image corresponds to an idea created in the consumer's mind, which differs from the actual image.

- The image as an icon: the image as an iconic representation of an object, or rather, the mental representation of a brand as an icon.

- The image as an attitude: the association of the concept of image with the concept of attitude, or rather, the image is based on a cognitive dimension (how consumers perceive a brand), an affective dimension (emotions generated by the brand) and a behavioral dimension (which largely influences subsequent buying behavior, and is an important predictive indicator).

As stated above, brand image is characterized by a strong subjective component and is therefore difficult to work with. In this way, one of the most important aspects for brand management is the existence of Public Relations (PR) which, according to Avenarius (1993), becomes a tool enabling organizations to work strategically with brand image to develop the desired corporate image when used with consistent and coherent communication.

Specifically, Hunt and Grunig (1994) define the strategy of PR as the process of managing communication between an organization and its public (market). Referring to the process required by PR, Marken (1994) points out that such relationships make it possible to protect the image and reputation of organizations. Thus image and reputation become critical elements for business success and are not abstract, and reputation is the set of values that stakeholders attach to an organization based on their perception and interpretation of its brand image.

However, the image of a brand in the market does not always coincide with the image that the company intends to transmit or the actual brand image. As such, organizations tend to consider three (3) different levels for the analysis of brand image:

- The analysis of the perceived image - how the target segment sees and perceives the brand (through a brand image study).

- The analysis of the actual image (strengths and weaknesses), as perceived by the company and based on an internal audit.

- Analysis of the desired image, i.e., how the company wants to be perceived by the target segment.

The study of these three (3) levels of brand image is justified by the fact that there are considerable di- 
fferences between these different levels, which could undermine the objectives of the company, preventing the maximized usefulness of the efforts made by those responsible for the brand. In other words:

- There may be important differences between reality and the perception of the brand in the market and these differences may be reflected positively or negatively in the brand image.

- There may be a gap between the desired brand image and its know-how, undermining the credibility of the company's strategy. This may be a sore point for business services, where professionals who come into contact with consumers contribute directly to the creation of the company's brand image, and become ambassadors for the brand. In this sense, internal marketing plays an important role.

To understand the perceived brand image it is necessary to assess three (3) levels of market response, successively measuring cognitive, emotional and behavioral responses. Measurements of attitude in relation to a set of attributes are particularly useful because it makes it possible to build an image profile, using a perceptual map in addition to the "importance-performance" matrix.

Thus, numerous studies have found that brand image strongly influences both the emotional response of consumers to products and their purchasing behavior (Cohen, 1982; Greenwald and Leavitt, 1984, Smith and Ellsworth, 1985). McInnis and Price (1987) report that brand image ultimately influences purchase intention. The timing of a purchase is also influenced by the image consumers have of a brand.

\section{Destination image}

The organizational reality is similar in the context of Tourism Marketing, given that the image tourists have of tourist destinations is an element of major importance there (Hunt, 1975; Chon, 1991; Echtner and Ritchie, 1991; Aaker, 1996, Gartner, 1996; Kapferer, 1997; Buhalis, 2000; Laws, Scott and Parfitt, 2002; Tasci and Gartner, 2007; Rial, and García Varela, 2008), ultimately influencing the final choice or behavioral intention (Chen and Tsai, 2007).

However, pioneering studies on the image of tourist destinations, dating from the 1970s and also the 1980s present some theoretical and conceptual limitations (Fakeye and Crompton, 1991; Echtner and Richie, 1993; Gartner, 1993; Gallarza, Gil, and Calderon, 2002).

Lawson and Baud Bovy (1977) define the concept of destination image as the expression of all objective knowledge, prejudices, imagination and emotional thoughts of an individual or group about a particular location. Other authors define the image as the sum of all beliefs, ideas and impressions that people associate with a destination (Crompton, 1979; Kotler, Haider and Rein, 1993).

Valls (1992) presents a definition from the consumer's point of view, defining the brand image of a country as a set of consumer perceptions. Bigné, Sánchez and Sánchez (2001) define destination image as the subjective interpretation of reality by the tourist. Therefore, the image tourists have of a destination is largely subjective because it is based on the perceptions each tourist has of all of the destinations they have been to or have heard of (San Martín and Rodriguez, 2008). Its ambiguous, subjective and immaterial nature, and its large number of elements and attributes makes it complicated to define and no consensus has been reached about this yet (Ahsen, 1977, Aaker, 1991, 1996, Kapferer, 1991; Aaker and Joachimsthaler, 2000, García, 2002).

However, the latest guidelines for Tourism Marketing admit that the development of the image of a tourist destination is based on the consumer's rationality and emotionality, and as the result of the combination of two (2) main components or dimensions (Moutinho, 1987, Gartner, 1993; Baloglu and Brinberg, 1997; Walmsley and Young, 1998; Baloglu and McCleary, 1999a, 1999b; Dobni and Zinkhan, 1990; Lin, Duarte, Kerstetter and Hou, 2007):

- Perceptual and cognitive: there is a primacy of the importance and value given to each attribute of tourist destinations. In other words, the destination image is evaluated by the attributes of its resources and attractions (Stabler, 1995) which motivate tourists to visit that destination (Alhemoud and Armstrong, 1996, Schneider and Sönmez, 1999; Gallarza, Saura and Garcia, 2002; Beerli and Martín, 2004; Govers and Go, 2005).

- Affective: referring to feelings and emotions raised by tourist destinations (Keller, 1993; Rial et al., 2000; Rial, García and Varela, 2008). This emotional component is also strongly affected by the motivations of tourists (Beerli and Martín, 2004).

It is also important to note that the cognitive component of the image has a considerable impact on the affective component (Holdbrook, 1978, Russell and Pratt, 1980; Anand, Holbrook and Stephens, 1988, Stern and Krakover, 1993, Lin et al. 2007; Ryan and Cave, 2007). The socio-demographic characteristics of tourists also greatly influence the cognitive and affective assessment of the overall image (Beerli \& Martín, 2004).

Therefore, the overall image of the destination is a combination of cognitive and affective components (Ma- 
zursky \& Jacoby, 1986, Stern \& Krakover, 1993), whereas the actual experience of having been on vacation at a tourist destination has an important effect on the destination image from a cognitive and emotional point of view (Beerli \& Martín, 2004).

\section{Formation of the image of a tourist destination}

As the result of a perceptual and cognitive process, the destination image is formed from several sources of information (reference groups, group membership, media, etc.). Thus, any person can build an image of any destination (in their mind) without ever having been there. In other words, the image of the destination will be based on historical, political, economic and social information which, in turn, will shape the image that the person already held (Echtner \& Richie, 1991). The value system of each individual will eventually influence the image that they develop of a tourist destination, by acting as a selective attention filter (Moutinho, 1987). Also the country of origin of the person influences the image that they build of tourist destinations (Bonn, Joseph \& Dai, 2005).

Lubbe (1998) proposes a framework that explains the construction of the primary image of a tourist destination, identified in Figure 1.

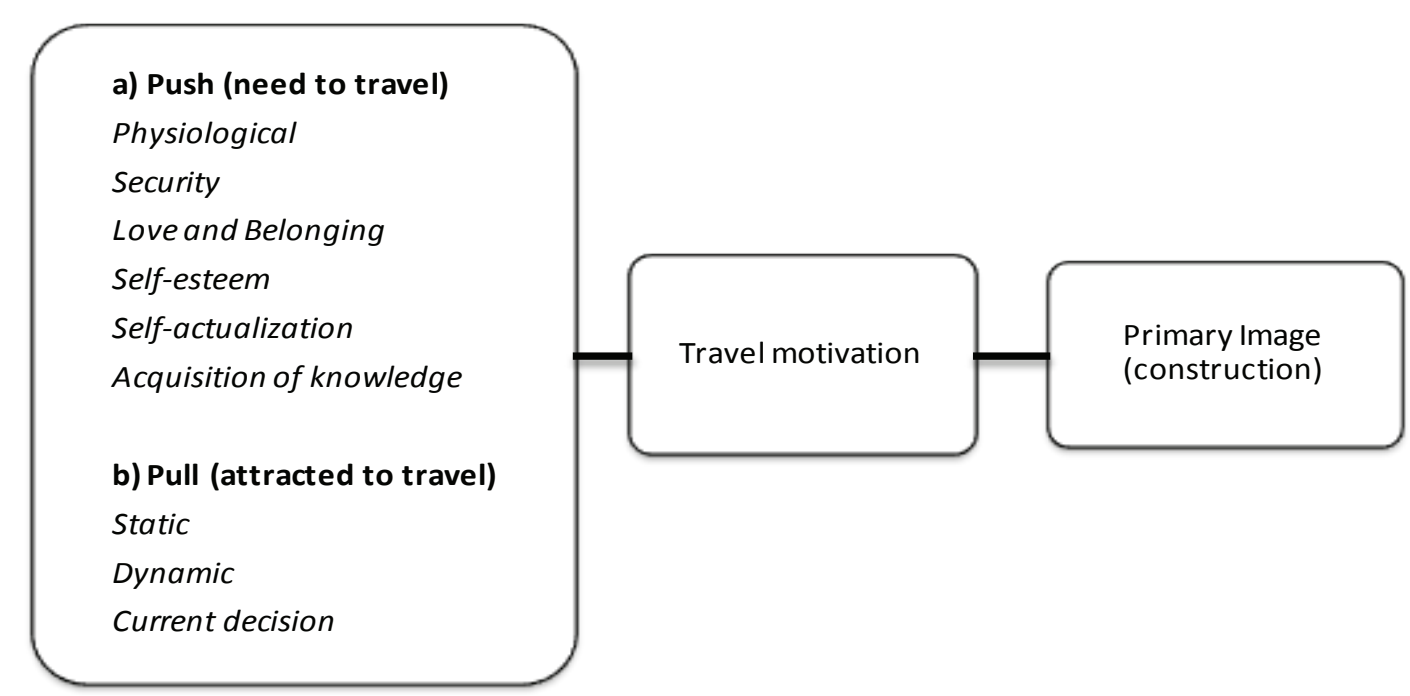

Figure 1. Construction of the primary image (Adapted from Lubbe, 1998) visit to the tourist destination are very important for the destination image created in the minds of tourists. Meanwhile, level of education and (socio-psychological) motivation to travel influence affective assessment, i.e., feelings and emotions (Moutinho, 1987; Gartner, 1993; Baloglu and Brinberg, 1997; Walmsley \& Young, 1998). Indeed, both perceptual-cognitive and affective assessment configures the overall image that people develop about a tourist destination (Baloglu and McCleary, 1999a).

In this context, Govers, Go and Kumar (2007) state that the tourist's personality becomes an important factor when choosing the kind of destination to visit (beach, mountain, etc.) and that personality traits influence the differentiation between destinations (Murphy, Moscardo and Benckendorff, 2007).

Demographic variables also strongly influence the image tourists have of tourist destinations (Firmino Santos \& Carneiro, 2006). Beerli and Martín (2004) report that motivation, socio-demographic variables and experience are important factors for forming the image of a tourist destination.

More recently, other authors suggest that psychological factors such as a tourist's motivations and cultural values strongly influence the construction of the image of a tourist destination even before it is visited

(San Martín \& Rodriguez, 2008). In this context, Stabler (1988) identifies some factors which influence the process of forming the image of a tourist destination, presented in Figure 3.

With reference to the components of the image of a tourist destination, one theoretical orientation states that the cognitive component precedes the emotional component in the overall image structure (Holbrook, 1978, Russell and Pratt, 1980; Anand,
Baloglu and McCleary (1999a) propose a PATH model to explain the process of forming the image of a tourist destination (Figure 2).

Sources of information, age and level of education influence cognitive and perceptual assessment.

More specifically, the study carried out by Tasci (2007) demonstrates that age, race, and a previous
Holbrook and Stephens, 1988, Stern and Krakov, 1993).

Meanwhile for the general image of a destination, some authors suggest that these two (2) (cognitive and affective) components determine whether that general image will be a positive or negative assessment of the destination (Baloglu and McCleary, 1999a, 1999b, Stern and Krakover, 1993). 


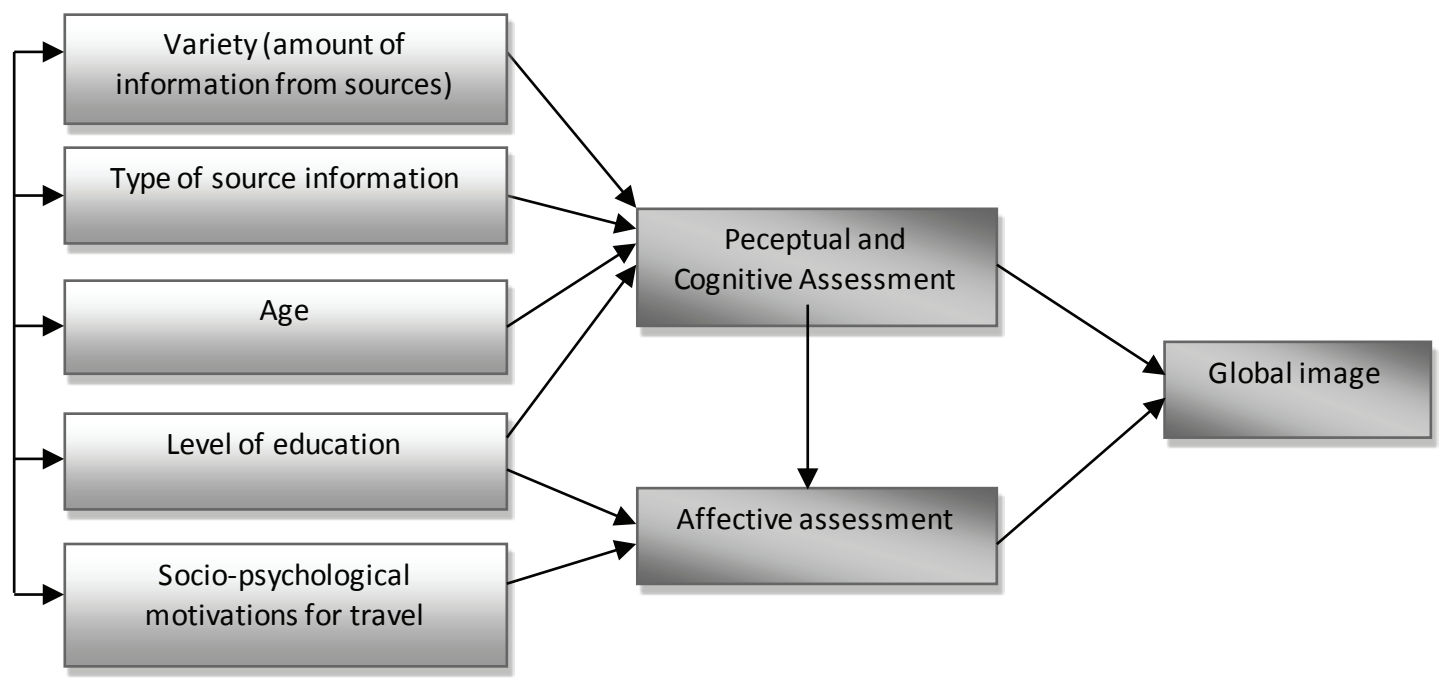

Figure 2. PATH model of the determinants of the destination image (Baloglu \& MacCleary, 1999a)

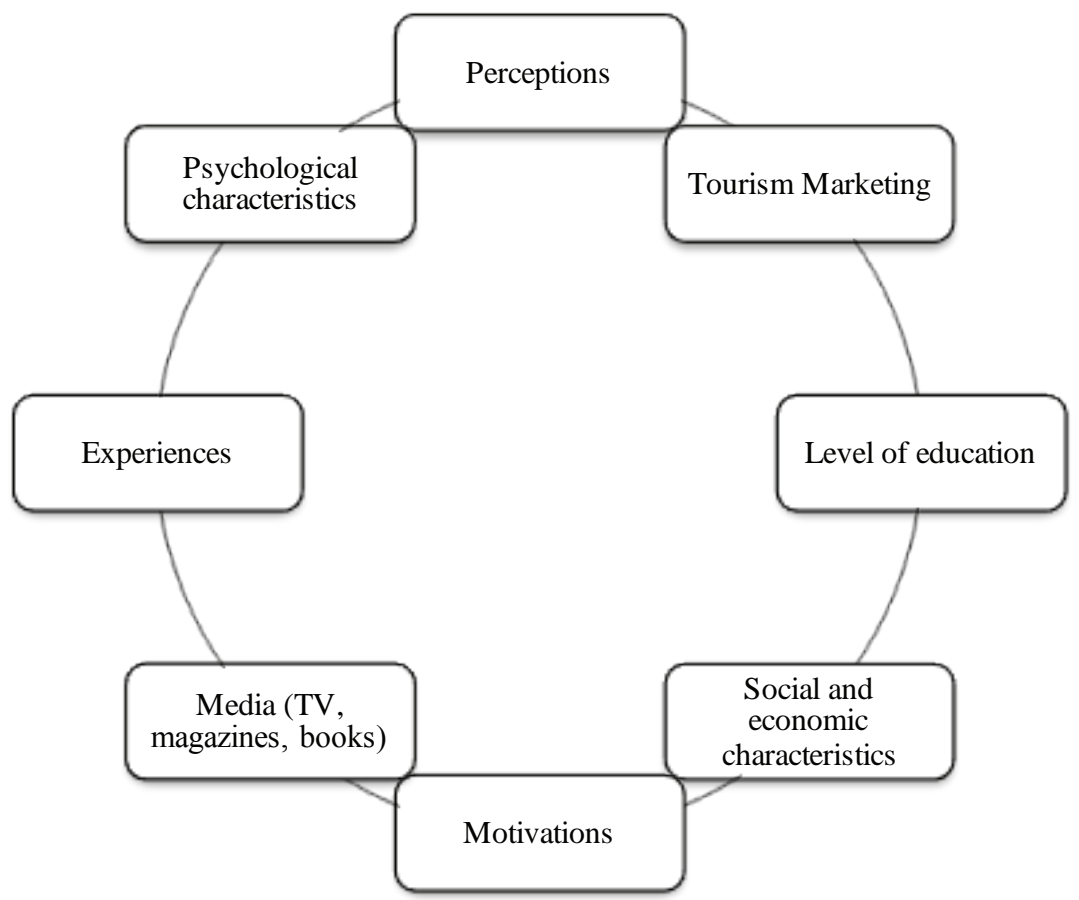

Figure 3. Factors influencing the formation of the image of tourism destinations. (Adapted from Stabler, 1988)

Image is therefore the most important concept for interpreting the choices made by tourists (Mayo, 1973; Govers and Go, 2003) but they warn that it is difficult for tourists to gain a clear image of a destination without having visited before (Govers and Go, 2003).

In this context where the tourist has no experience in locum, there are three factors that affect their image of a tourist destination: tourism motivations, demographic variables and information about the destination
(Echtner and Ritchie, 1993; Baloglu and McCleary, 1999b; Beerli and Martin, 2004).

For this last factor - information about the destination - sources of information are magazines, celebrities (opinion leaders), television and the internet, which will ultimately influence the image that potential tourists will have of a tourist destination (Gartner, 1989; Vasudavan and Standing, 1999, Wang and Fesenmaier, 2005; Govers, Go and Kumar, 2007). In information 
technology, Govers and Go (2005) report that social networks on the Internet can play an important role as a source of inside information for potential tourists, whether through images, interaction and multimedia on the Web, making it possible to configure a stronger and lighter image of a destination (Govers \& Go, 2003).

Gunn (1972) identifies two (2) levels for the image of a tourist destination, based on the type of information transmitted to the tourist:

- Organic image: i.e. all of the information transmitted unintentionally by representatives of tourism destinations. Such information may be transmitted either via television, radio, books on geography or history, newspapers, magazines, or by people living at a tourist destination.

- Induced image: i.e. the image formed by the promotions and communications of the tourism organizations involved in a region.

It is naturally true, in this context, that both reference or membership groups and opinion leaders can have a powerful influence on the perception tourists have of a particular destination.

\section{Development of the image of a tourist destination}

Tocquer and Zins (2004) studied the perceptual influences on tourists with regard to a particular destination, and proposed the grouping of images into four (4) stages of development:

- Vague and unrealistic image - stems from advertising, education and word of mouth dissemination. It is formed before the tourist travels. In this sense, people see a travel vacation as something healthy.

- Distortion of the image - at this stage, the person decides to go on vacation, choosing the time spent on vacation, destination and type of tourism product. It is during this period that the image of vacation is changed, clarified and expanded. The image developed becomes clearer once the vacation plan has been finalized.

- Improved image - in this third (3rd) stage, we have the vacation experience itself. When there is direct experience of the tourism product, the image is improved by canceling out incorrect or distorted elements and strengthening elements that prove to be correct.

- Resulting image - this fourth (4th) stage refers to the recent memory of the vacation experience and can lead to nostalgia, regret or fantasy. Thereafter, a set of new images will be triggered that will affect future decisions about that same tourism product.

Meanwhile, other authors propose an interpretation of the image before visiting the tourist destination and with the image being built after the visit. Thus, Phelps (1986) defines the primary image as the image built after the visit to the destination and the secondary image is seen as the image built before the visit to the destination. Later, Gunn (1988) and Mansfeld (1992) distinguished two (2) types of images in the secondary image: the organic image (informal image for Mansfeld) that derives from non-commercial information (independent of destination management) and the induced the image (formal image for Mansfeld) with respect to information conveyed by the commercial organization responsible for the destination (figure 4).

Based on this typology, Fakeye and Crompton (1991) developed a path model that illustrates the route taken by tourists in search of information. Thus, these authors explain that a potential tourist has a secondary organic image of a set of destinations (share of mind). Then,

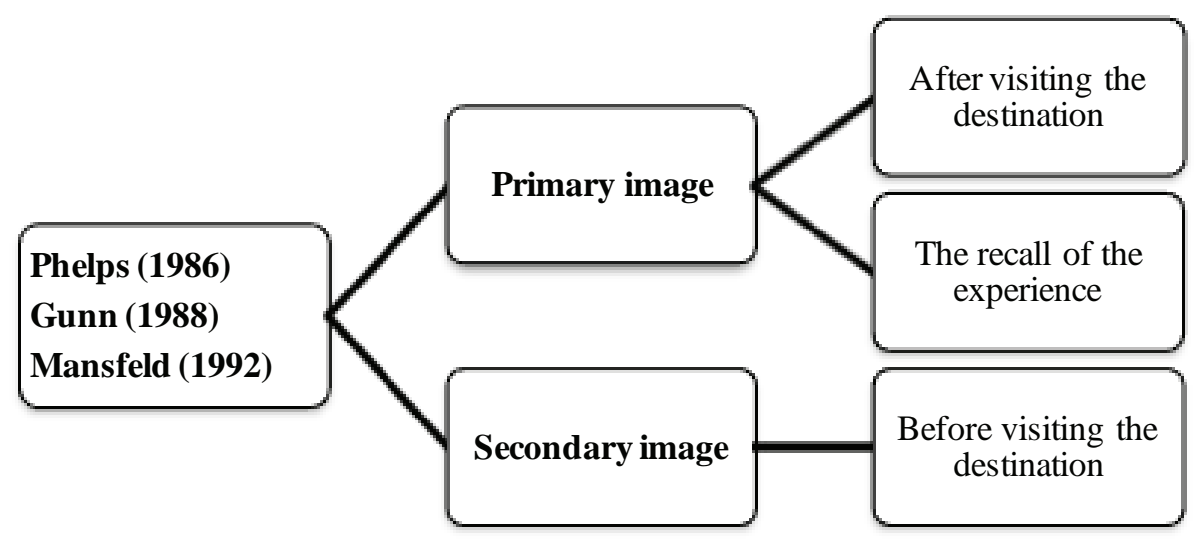

Figure 4. Image types according to type of knowledge (Adapted from Phelps, 1986, Gunn, 1998 and Mansfeld, 1992) 


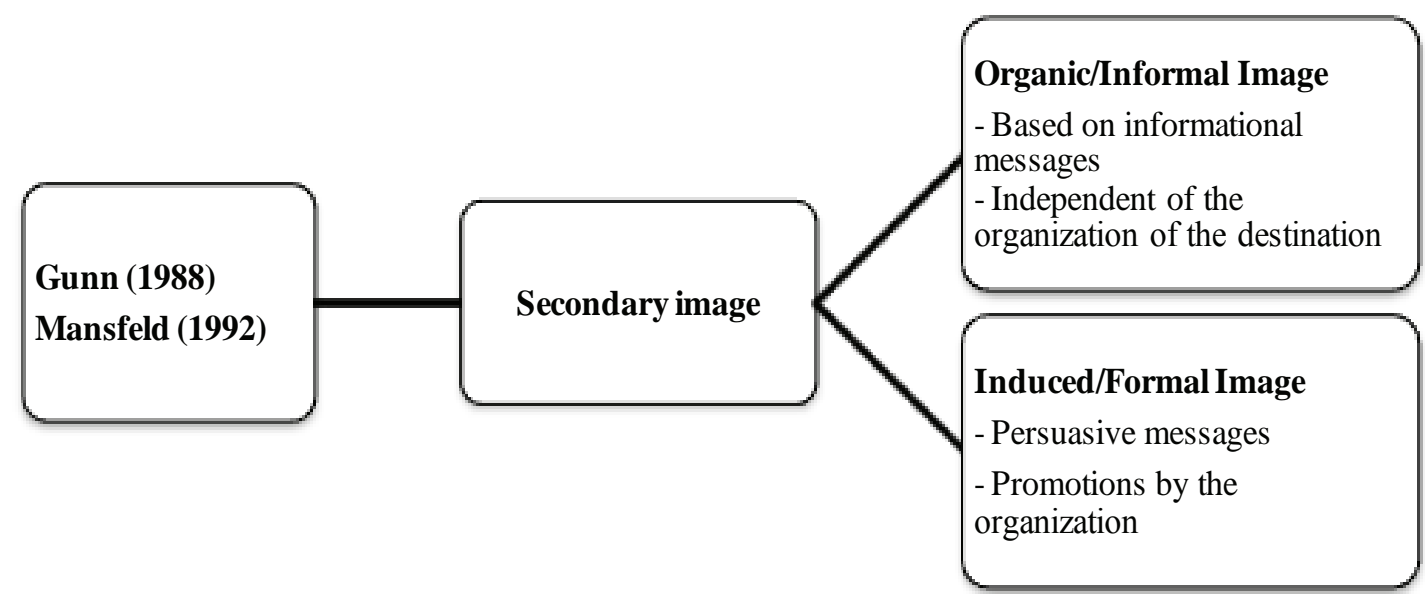

Figure 5. Types of secondary image (Adapted from Gunn, 1998 and Mansfeld, 1992)

based on their motivations and perceptions, they will actively seek information. However, the fact that potential tourists have a strong or a weak organic image and/ or direct or indirect experience with the tourist destination will influence the amount of information sought and efforts made in this search process. The different alternatives found will be assessed on the basis of the initial organic image, personal experiences and the induced formal image (sent by the organization responsible for the destination). Then the destination visited will develop the primary image that, in turn, will influence the future search process.

The same authors also suggest that for a more advantageous promotion of a destination, informational messages should be used in the organic phase of the image, while persuasive messages would be appropriate for the induced phase of the image. During the primary image stage, the authors claim that messages that remind tourists of previous experiences are more beneficial.

\section{Effects of the brand image of a tourist destination}

As can be seen in the various definitions of the concept of the image of a tourist destination, the image in itself represents the tourist's tendency to choose or reject a given destination. As such, the image influences the attitude that tourists develop towards destinations, which ultimately influences the buying decision process.

Mayo (1973), examines images and regional travel behavior, and states that the image of a destination is a key factor when a tourist chooses the travel destination. They also indicate that the image that tourists develop after traveling to a specific destination is more important than corresponding to what the tourist destination commits itself to offering. With this in mind, Gunn (1972) states that it is unlikely that tourists will visit a specific tourist destination that they do not like.

In this context, Lim and O'Cass (2001) report that a destination with a strong image is more easily differentiated from its competitors, and a tourist destination with stronger and more positive image more likely to be considered and selected at the end of the decisionmaking process (Mayo, 1973, Hunt, 1975; Goodrich, 1978; Pearce, 1982; Woodside \& Lysonski, 1989, Ross, 1993; Milman and Pizan, 1995, Chen and Kerstetter, 1999; Bigné, Sánchez and Sánchez, 2001; Sönmez and Sirakaya , 2002).

A tourist destination with a strong and consolidated image in the market has a better guarantee of prosperity (Fakeye and Crompton, 1991), and this factor is an important influence on the consumer behavior of tourists (Ashworth and Goodall, 1988; Manfeld, 1992; Bigné et al., 2001).

Thus, image becomes one of the main assets of a tourist destination and one which has the most influence on the decision taken by of tourists when choosing a destination. However, the ambiguity and subjectivity which results from the multi-attribute definition (Rey-
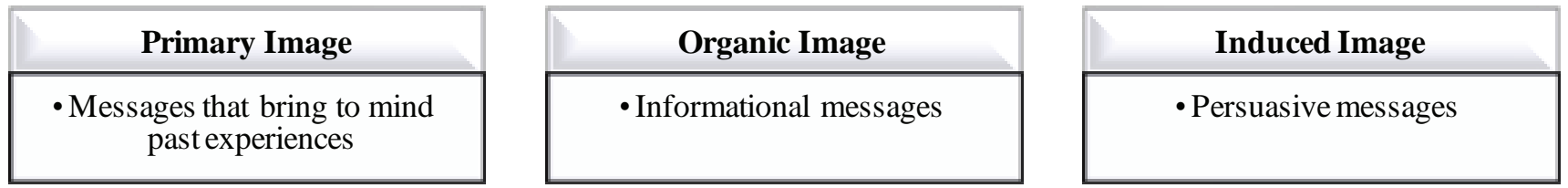

Figure 6. Type of information used depending on the type of image (Addapted from Fakeye \& Crompton, 1991) 
nolds and Guttman, 1984) that is eradicated from their concept leads to a multicollinear effect, making the measurement of its contribution less precise than desired (Gallarza et al., 2002).

\section{Conclusion}

The globalization process has expanded markedly in recent years, increasing the difficulties experienced in virtually every sector of the economy. The tourism sector is no exception, and has been the target of the latest economic and financial crisis

In this sense, those responsible for tourism management should be aware of all elements that will improve their products. This is why Brand Image has become one of the most important elements of a tourist destination in recent years, is directly reflected in their positioning and ultimately increases the likelihood of commercial success or failure for each destination.

Thus, this work is a theoretical approach to and a review of empirical work on the origin and development of brand image and its impact in the management of tourist destinations.

In this context, the image of a destination can be divided into two stages - the primary image - developed after visiting a tourist destination and - the secondary image - the image created before a person has traveled to a particular destination. Some authors suggest that it is more strategic to use messages recalling past experiences during the primary image, while in the secondary image stage it is more useful to communicate information and persuasive messages about the destination.

Variables such as age, race, the fact that a person has visited a destination before, their level of education, motivation and cultural values strongly influence the image of a destination which is created. In this sense, working with all of these variables is a unique opportunity to strengthen a positive image of a destination and thus to increase the likelihood of a particular tourist destination being selected.

In short, the destination image is one of the most important elements of a tourist destination, and becomes a critical factor for the success or failure of tourism management. As such, the image of a destination should be analyzed using a Research, Development and Innovation strategy, supported by multivariate methodologies to discover its main characteristics and subsequent positioning.

\section{References}

Aaker, D.A.

1991 Managing brand equity: capitalizing on the value of a brand name, The Free Press, NY.

Aaker, D.A.

1996 Criando e administrando marcas de sucesso, Fu- tura, São Paulo.

Aaker, D.A. \& Joachimsthaler, E.

2000 Brand leadership: Building assets in the information society, Free Press, NY.

Ahsen, A.

1977 Eidetics: An overview, Journal of Mental Imagery, 1 (1), 5-38.

Alhemoud, A.M. \& Armstrong, E.G.

1996 Image of tourism attractions in Kuwait, Journal of Travel Research, Spring, 24-27.

Anand, P., Holbrook, M.B. \& Stephens, D.

1988 The formation of affective judgements: the Cognitive-Affective Model versus the independence hypothesis, Journal of Consumer Research, 15, 386391.

Ashworth, G.J. \& Goodall, B.

1988 Tourist images: Marketing Considerations, Marketing in the tourism industry - the promotion of destination regions, B. Goodall \& G. Ashworth (Eds.), Routhlegde, UK, 213-237.

Avenarius, $\mathrm{H}$.

1993 Introduction: Image and public relations practice, Journal of Public Relations Research, 5 (2), 65-70.

Beerli, A. \& Martín, J.D.

2004 Tourists' characteristics and the perceived image of tourist destination: a quantitative analysis - A case study of Lanzarote, Spain, Tourism Management, 25, 623-636.

Bigné, E., Sánchez, M.I. \& Sánchez, J.

2001 Tourism image, evaluation variables and after purchase behaviour: inter-relationship, Tourism Management, 22, 607-616.

Baloglu, S. \& Brinberg, D.

1997 Affective images of tourism destination, Journal of Travel Research, 35 (4), 11-15.

Baloglu, S. \& McCleary, K.W.

1999a A model of destination image formation, Annals of Tourism Research, 35 (4), 11-15.

Baloglu, S. \& McCleary, K.W.

1999b US international pleasure travellers" images of four Mediterranean destinations: a comparison of visitors and nonvisitors, Journal of Travel Research, 38 (2), 114-129.

Baüerle, R.

Meaning, use and interpretation, De Gruyter, Berlin.

Beerli, A. \& Martín, J.D.

2004 Tourists' characteristics and the perceived image of tourist destinations: a quantitative analysis - A case study of Lanzarote, Spain, Tourism Management, 25, 623-636.

Bonn, M.A., Joseph, S.M. \& Dai, M.

2005 International versus Domestic Visitors: An Exa- 
mination of Destination Image Perceptions, Journal of Travel Research, 43 (3), 294-301.

Buhalis, D.

2000 Marketing the competitive destination of the future, Tourism Management, 21 (1), 97-116.

Capriotti, V.P.

1992 La imagen de empresa, El Ateneo, Barcelona.

Chen, P.J. \& Kerstetter, D.L.

1999 International student's image of rural of Pennsylvania as a travel destination, Journal of Travel Research, 37, 256-266.

Chen, C.F \& Tsai, D.G.

2007 How destination image and evaluative factors affect behavioral intentions? Tourism Management, 28 (4), 1115-1122.

Chon, K-S.

1991 Tourism destination image modification process. Marketing implications, Tourism Management, 12 (1), 68-72.

Cohen, D.

1982 Publicidad comercial, Diana, México.

Costa, J.

1987 Image global, CEAC, Barcelona.

Crompton, J.L.

1979 Motivations for Pleasure Vacations, Annals of Tourism Research, 6 (4), 408-424.

Dobni, D. \& Zinkhan, G.M.

1990 In search of brand image: a foundation analysis, Advances in Consumer Research, 17, 110-119.

Echtner, C.M. \& Ritchie, J.R.B.

1991 The measuring and measurement of destination image, The Journal of Tourism Studies, 2 (2), 2-12.

Echtner, C.M. \& Ritchie, J.R.B.

1993 The measurement of destination image: an empirical assessment, Journal of Travel Research, 31 (4), 3-13.

Fakaye, P.C. \& Crompton, J.L.

1991 Image differences between prospective, first-time and repeat visitors to the lower Rio Grande valley, Journal of Travel Research, 30 (2), 10-16.

Ferreira, S.D., Rial, A. \& Varela, J.

2009 Post Hoc Tourist Segmentation with Conjoint and Cluster Analysis, Pasos, Revista de Turismo y Patrimonio Cultural, 7 (3), 491-501.

Rial, A., Ferreira, S.D. \& Varela, J.

2009 Análise Conjunta: Uma Aplicação Ao Estudo das Preferências dos Consumidores, Portuguese Journal of Marketing, 25.

Firmino, N., Santos, S. \& Carneiro, J.M.

2006 A importância das características socio-demográficas dos visitantes enquanto determinantes da viagem dos destinos turísticos: O caso de Aveiro, Revis- ta Turismo \& Desenvolvimento, 5, 41-52.

Gallarza, M., Gil, I. \& Calderón, H.

2002 Destination image. Towards a conceptual framework, Annals of Tourism Research, 29 (1), 56-78.

Gallarza, M.G., Saura, I. G. \& García, H. C.

2002 Destination image: towards a conceptual framework, Annals of Tourism Research, 29, 56-78.

García, A.

2002 Una propuesta metodológica para le medición de la Imagen de Marca, Universidad de Santiago de Compostela, Tesis Doctoral no publicada.

Gartner, W.C.

1989 Temporal influence on image change, Annals of Tourism Research, 13, 635-644.

Gartner, W.C.

1993 Image formation process, Journal of Travel and Tourism Marketing, 2 (2/3), 191, 215.

Gartner, W.C.

1996 Tourism Development. Principles, Process and Policies, John Wiley \& Sons Inc.

Goodrich, J.N.

1978 A new approach to image analysis through Multidimensional Scaling, Journal of Travel Research, 17 (2), 2-7.

Govers, R. \& Go, F.

2003 Deconstructing destination image in the information age, Information Technology and Tourism, 6 (1), 13-29.

Govers, R. \& Go, F.

2005 Projected destination online: Website content analysis of picture and text, Information Technology and Tourism, 7 (2), 1-18.

Govers, R., Go, F.M. \& Kumar, K.

2007 Promoting Tourism Destination Image, Journal of Travel Research, 46 (1), 15-23.

Greenwald, A.G. \& Leavitt, C.

1984 Audience involvement in advertising: Four levels, Journal of Consumer Research, 11, 581-592.

Gunn, C.A.

1972 Vacationscape: Designing Tourist Regions, Taylor \& Francis, Washington.

Gunn, C.A.

1988 Vacationscape: Designing Tourist Regions (2nd Ed.), Van Nostrand, NY.

Holbrook, M.B.

1978 Beyond attitude structure: toward the informational determinants of attitude, Journal of Marketing Research, 15, 545-556.

Hunt, J.D.

1975 Image as a factor in tourism development, Journal of Travel Research, 13, 1-7.

Kapferer, J.N.

1991 As Marcas, Capital da Empresa, CETOP, Portu- 
gal.

Kapferer, J.N.

1997 Strategic Brand Management, Kogan Page, UK.

Keller, K.L.

1993 Conceptualizing, measuring and managing customer-based brand equity, Journal of Marketing, 57 (January), 1-22.

Kotler, N., Haider, D.H. \& Rein, I.

1994 Mercadotecnia de localidades, Diana, México.

Laws, E., Scott, N. \& Parfitt, N.

2002 Synergies in destination image management. A case study and conceptualization, The international Journal of Tourism Research, 4 (1), 39-55.

Lawson, F. \& Baud Bovy, M.

1977 Tourism and recreational development, Architectural press, London.

Lim, K. \& O'Cass, A.

2001 Consumer brand classifications: an assessment of culture-of-origin versus country-of-origin, Journal of Product \& Brand Management, 10 (2), 120-136.

Lin, C-H., Duarte, B., Kerstetter, D.L. \& Hou, J-S.

2007 Examining the Role of Cognitive and Affective Image in Predicting Choice Across Natural, Developed, and Theme-Park Destinations, Journal of Travel Research, 46, 183-194.

Lubbe, B.

1998 Primary Image as a Dimension of Destination Image: An Empirical Assessment, Journal of Travel and Tourism Marketing, 7 (4), 21-43.

Mansfeld, Y.

1992 From motivation to actual marketing, Annals of Tourism Research, 19, 399-419.

Marken, G.A.

1994 Corporate image - we all have one, but few work to protect and project it. Public Relations Quaterly, Winter.

Mayo, E.J.

1973 Regional images and regional travel behavior, Proceedings of the Travel Research Association Conference, 211-218.

Mazursky, D. \& Jacoby, J.

1986 Exploring the development of store images, Journal of Retailing, 62 (2), 145-165.

McInnis, D.J. \& Price, L.L.

1987 The role of imagery in information processing: review and extension, Journal of Consumer Research, 13, 473-491.

Milman, A. \& Pizan, A.

1995 The role of awereness and familiarity with a destination: the Central Florida case, Journal of Travel Research, 33 (3), 21-27.
Moutinho, L.

1987 Consumer behaviour in tourism, European Journal of Marketing, 21 (10), 5-44.

Murphy, L., Moscardo, G. \& Benckendorff, P.

2007 Using Brand Personality to Differentiate Regional Tourism Destinations, Journal of Travel Research, 46 (1), 5-14.

Paivio, A.

1971 Imagery and verbal processes, Holt, Rinehard \& Winston, NY.

Pearce, P.L.

1982 Perceived changes in holiday destinations, Annals of Tourism Research, 9 (2), 145-164.

Phelps, A.

1986 Holiday destination image: the problem of assessment, Tourism Management, 7 (3), 168-180.

Reynolds, T.J. \& Guttman, J.

1984 Advertising is image management, Journal of Advertising Research, 24, 27-37.

Rial, A., Varela, J., Braña, T. \& Lévy, J.P.

2000 El valor de la marca a partir de su relación con el consumidor, Psicothema, 12 (2), 247-254.

Rial, A., Varela, J. \& García. A.

2008 Una aplicación metodológica para el estudio de la imagen de marca de un destino turístico, Pasos - Revista de Turismo y Patrimonio Cultural, 6 (1), 1-10.

Ross, G.F.

1993 Ideal and actual images of backpacker visitors to Northern Australia, Journal of Travel Research, 21 (3), 54-57.

Russel, J.A. \& Prat, G.

1980 A description of affective quality attributed to environment, Journal of Personality and Social Psychology, 38, 311-322.

Ryan, C. e Cove, J.

2007 Structuring Destination Image: A Qualitative Approach, Journal of Travel Research, 44 (2), 143-150.

San Martín, H. \& Rodríguez, I.A.

2008 Exploring the cognitive-affective nature of destination image and the role of psychological factors in its formation, Tourism Management, 29 (2), 263-277.

Sanz de la Tajada, L.A. (1996). Auditoria de la imagen de empresa. Métodos y técnicas de estudio de la imagen, Síntesis, Madrid.

Schneider, L. \& Sönmez, S.

1999 Exploring the tourist image of Jordan, Tourism Management, 20, 539-542.

Sönmez, S. \& Sirikaya, E.

2002 A distorted Destination Image? The case of Turkey, Journal of Travel Research, 41 (2), 185-196.

Stabler, W.J.

1995 The image of destination regions: theoretical and empirical aspects, Marketing in the Tourism Indus- 
try: the Promotion of Destination Regions, Goodall, B. \& Ashworth, G., 133-161, Croom Helm, London.

Stern, E. \& Krakover, S.

1993 The formation of a composite urban image, Geographical Analysis, 25 (2), 130-146.

Tasci, A.D. (2007). Assessment of factors influencing destination image using a multiple regression model, Tourism Review, 62 (2), 23-30.

Tasci, A.D. \& Gartner, W.A.

2007 Destination Image and Its Functional Relationships, Journal of Travel Research, 45 (4), 413-425.

Tocquer, G. e Zins, M.

2004 Marketing do Turismo, Instituto Piaget, Portugal.

UNWTO

2008 Tourism 2020 Vision forecasts, World Tourism Organization.

Valls, J.F.

1992 La imagen de marca de los países, McGraw-Hill, Madrid.

Vasudan, T. \& Standing, C.

1999 Web Technology Diffusion and Service Offerings by Travel Agencies, International Conference on System Sciences, Hawaii.

Walmsley, D.J. \& Young, M.

1998 Evaluative images and tourism: the use of perceptual constructs to describe the structure of destination images, Journal of Travel Research, 36 (3), 65-69.

Wang, Y. \& Fesenmaier, D.

2005 Identifying the success factors of web-based marketing strategy: An investigation of convention and visitors bureaus in the United States, Journal of Travel Research, 43 (3), 1-11.

Woodside, A.G. \& Lysonski, S.

1989 A General Model of Traveler Destination Choice, Journal of Travel Research, 27 (4), 8-14.
Recibido:

$10 / 02 / 10$

Reenviado:

$10 / 01 / 11$

Aceptado:

$25 / 01 / 11$

Sometido a evaluación por pares anónimos 